\title{
ČAPV očima bývalé předsedkyně
}

\author{
Milada Rabušicová
}

Masarykova univerzita, Filozofická fakulta, Ústav pedagogických věd

Českou asociaci pedagogického výzkumu jsem měla tu čest vést čtyři roky, a to v letech 2004 až 2008. Samozřejmě jsem na to nebyla sama, ale společně $\mathrm{s}$ dalšími členy výboru jsme tvořili tým, který se rozhodl pracovat ve prospěch této organizace a pokusit se její aktivity posunout o kousek dál. Chci se zastavit u sousloví „pracovat ve prospěch organizace“, které jsem v předchozí větě použila. Myslím, že dủležitá změna, která tehdy nastala, spočívala v tom, že se nám podařilo spojovat práci pro celek, tedy jakýsi altruistický prvek, s prací sama na sobě, tedy prvek osobního a profesního rozvoje. To podle mého názoru neslo dobré ovoce právě proto, že společný a individuální zájem byly v souladu. Domnívám se, že v podobném duchu pokračuje i stávající výbor vedený doc. Petrem Urbánkem, který aktivity ČAPV rozvinul opět o kousek, lépe řečeno o pěkný kus, dál.

Česká asociace pedagogického výzkumu je dnes silná a dobře řízená organizace. To neznamená, že je dokonalá a že nemusí zvládat nejrůznější výzvy, které před ní stojí. Jsem v tomto ohledu ale optimistická a svůj optimismus zakládám na předcházející zkušenosti s řešením různorodých výzev, jež stály před asociací v minulosti. U několika $\mathrm{z}$ nich se chci zastavit.

Vzpomínám si, že na jedné z prvních konferencí ČAPV, tuším, že to bylo v Olomouci, se veškeré prezentace odehrávaly v jedné místnosti. Vlastně nás bylo pár. Od té doby se naše konference opravdu rozrostly. Stačí se podívat do letošního konferenčního programu. A členů ČAPV a účastníků konferencí dále přibývá.

Pamatuji si, že nebylo úplně automatické přijímat výlučně či alespoň především výzkumné prezentace, a to navzdory názvu naší asociace. Trvalo několik let, než pedagogická obec přistoupila na to, že pedagogický výzkum by se neměl objevovat jen $\mathrm{v}$ názvu organizace, ale především $\mathrm{v}$ jejím zacílení a v obsazích prezentovaných sdělení. Dnes máme v konferenčním programu nejen výzkumné prezentace, ale také sympozia, metodologické sekce a postery. Je to úzus, o kterém se nemusíme vzájemně přesvědčovat.

Také si vzpomínám, že k tomu, aby se posílil pedagogický výzkum, bylo nutné začít pomáhat mladým kolegům - doktorským studentům. Dobrou cestou, 
kterou kdysi po vzoru evropské asociace ČAPV zvolila, bylo pořádání metodologicky zaměřených doktorských seminářů. Vím, jak nám velmi záleželo na tom, aby doktorské semináře byly poučné a inspirativní, a hledali jsme k tomuto zadání vhodné přednášející. Dnes jsou doktorské semináře pevnou a oceňovanou součástí programu každé konference ČAPV. A protože pedagogická výzkumnická obec se rozrůstá a nové „př́růstky“ se tímto způsobem začleňují, je to navíc dobrý způsob, jak udržovat věkově diverzifikovanou organizaci.

Byla také doba, kdy jsme jasně věděli, že je potřeba nastavit nějakou komunikační platformu, jež by překlenovala mezidobí mezi výročními konferencemi. Dlouho jsme si s tím nevěděli rady. Dnes vydává současný výbor Bulletin $\check{C} A P V$, který přesně takovou užitečnou platformu vytváří. Také si pamatuji, že byla doba, kdy se v naší asociaci vážně diskutovalo o tom, zda máme být členy Evropské asociace pedagogického výzkumu. Nebyly peníze na členský příspěvek a lidé se ptali, co jim to přináší. Naštěstí takové otázky si už neklademe. Ta doba už je pryč.

A konečně, vzpomínám si na už hezkou řádku společenských večerů, které jsme mnozí absolvovali a bavili se u toho, povídali, poznávali se také z jiné než čistě pracovní stránky. Když jsem začala jezdit na konference ČAPV, cítila jsem se jako naprostý elév a k mnoha lidem $\mathrm{z}$ oboru jsem vzhlížela jako k někomu velmi vzdálenému a nedostižnému. Dnes jsem ráda, že o nich mohu mluvit jako o kolegyních a kolezích. A za to jim patří můj dík, protože jsem se od nich mnoho naučila.

Jednou z otázek, kterými mě stávající předseda Petr Urbánek inspiroval k této vzpomínkové anabázi, byla otázka, „jak řídit neřiditelné“. Moje zahraniční zkušenost ze šestiletého působení jako vice-presidentka pro Evropu Světové organizace pro předškolní výchovu - OMEP ${ }^{1}$ mně ř́ká, že funkční je vytvořit rámec, strukturu pevné organizace zevnitř, a to vše jako podmínku pro iniciativu členů a členským skupin. Občas je dobré přijít se zastřešujícím projektem, který může oslovit členy $\mathrm{k}$ tomu, aby se $\mathrm{k}$ němu připojili a realizovali jej $\mathrm{v}$ daném rámci a současně podle vlastních představ. Jinými slovy, moje odpověd' na otázku, „jak řídit neřiditelné“, je: nesnažit se řídit, ale vytvářet prostor pro iniciativu ostatních a velmi, stále a opakovaně

Nevládní organizace, nejstarší v dané oblasti, založená již v roce 1948 v Praze, aktuálně s 25 členskými organizacemi evropskými a celkem 65 organizacemi ze zemí celého světa, respektovaná mezinárodně, spolupracující s UNESCO a s UNICEF. 
je v tom povzbuzovat. A vážit si toho, co dělají. Taková je moje zkušenost a současně podnět pro další rozvoj České asociace pedagogického výzkumu.

A jaké jsou aktuální výzvy? Soudím, že především otevřít organizaci více vnějšímu světu. Sami uvnitř už jsme docela dobře organizováni, nabýváme tedy na vnitřní síle, kterou bychom mohli ve větší míře uplatnit ve prospěch našeho a blízkých oborů a především praktických realizací, které s těmito obory souvisejí, tedy světa výchovy a vzdělávání, školství, vzdělávací politiky... Myslím, že to velmi dobře vystihuje metafora známá ze sociální politiky: „Mít pevné dno a otevřený strop."

Do dalších let přeji organizaci - ČAPV a každému jejímu členovi, aby jejich zájmy byly v souladu, aby se svými aktivitami a výsledky vzájemně podporovali a aby se jim všem společně dobře dařilo: jinak řečeno, abychom měli pevné dno a otevřený strop!

Zounek, J., \& Sudický, P. (2012). E-learning: učení (se) s online technologiemi. Praha: Wolters Kluwer.

Kniha přináší komplexní a u nás poměrně ojedinělý pohled na problematiku e-learningu. Čtenáři se seznámí s proměnami učení v souvislosti s rozvojem ICT, ale také s klíčovými teoriemi učení. Pozornost je věnována studentům i učitelům učícím (se) v době digitálních technologií. Autoři v knize využívají výsledků mnoha empirických výzkumů z oblasti e-learningu. Jednu ze stěžejních kapitol tvoří pedagogická typologie online technologií, která ukazuje možnosti i meze jejich využití v různých podobách výuky. Následující části jsou věnovány didaktickým otázkám přípravy kurzů s podporou online technologií a př́kladům využití vybraných online technologií ve výuce na vysoké škole. Důležitou součástí knihy je online podpora, která přináší celou řadu doplňujících informací. 